\title{
RANCANG BANGUN SISTEM MANAJEMEN LEGAL DRAFTING UNTUK MENDUKUNG TERTIB ADMINISTRASI
}

\author{
Dedeh Supriyanti ${ }^{1}$, Andri Cahyo Purnomo ${ }^{2}$, Ari Ismudiarti ${ }^{* 3}$ \\ ${ }^{1}$ Program Studi Komputer Akuntansi Universitas Raharja, ${ }^{2}$ Program Studi Sistem Informasi \\ Universitas Raharja, ${ }^{3}$ Program Studi Teknik Informatika Universitas Raharja \\ Email : ${ }^{1}$ dedeh@ raharja.info, ${ }^{2}$ andricahyo@ raharja.info, ${ }^{* 3}$ ismudiarti@ raharja.info
}

\begin{abstract}
Abstraksi
Legal drafting adalah pembentukan peraturan perundangan-undangan yang merupakan pembuatan peraturan perundang-undangan yang mencakup tahapan perencanaan, penyusunan, pembahasan, pengesahan atau penetapan dan pengundangan. Dalam pelaksanaanyannya, pada tahapan perencanaan terkadang ada beberapa hal yang terlewatkan, sehingga tidak masuk pada tahapan penyusunan, demikian juga pada tahap penyusunan, terkadang ditemukan beberapa hal yang seharusnya tidak dilaksanakan atau dilaksanakan pada tahapan pembahasan, hal ini terjadi karena tingganya tingkat manualisasi dan pengarsipan, sehingga sangat sulit dalam melakukan pendataan apa saja yang sudah dikerjakan atau yang belum dikerjakan. Berdasarkan hal-hal tersebut di atas, maka perlu membentuk suatu sistem yang baik dalam hal penyusunan sistem informasi regulasi sehingga dapat terwujud mekanisme penyusunan peraturan perundang-undangan berbasis teknologi manajemen informasi untuk membantu melaksanakan tupoksi sub bagian penyusunan peraturan perundang-undangan. Untuk dapat menyelesaikan ini, penulis menggunakan beberapa metode, mulai dari metode analisa data dan dokumen, kemudian dituangkan dalam bentuk rancangan menggunakan uml, dan tersimpan dalam database menggunakan MySql, yang diimplementasikan menggunakan bahasa pemrograman php.hasil yang diharapkan terciptanya regulasi tertib administrasi untuk mendokumentasikan peraturan (regeling) maupun keputusan (beschikking) yang tersusun dan terdokumentasikan secara baik.
\end{abstract}

Kata kunci: Sistem manajemen, Legal drafting, Tertib administrasi

\begin{abstract}
Legal drafting is the formation of legislation which is the making of legislation that covers the stages of planning, drafting, discussing, ratifying or stipulating and promulgating. In its implementation, at the planning stage sometimes there are some things that are overlooked, so that they are not included in the drafting stage, as well as at the preparation stage, sometimes found several things that should not have been carried out or carried out at the discussion stage, this happened because of the high level of manualization and archiving. so it is very difficult in carrying out data collection on everything that has been done or that has not been done. Based on the things mentioned above, it is necessary to establish a system that is good in terms of the preparation of regulatory information systems so that mechanisms can be established to formulate regulations based on information management technology to help implement the tasks and functions of the sub-division of legislation. To be able to complete this, the author uses several methods, starting from the method of analyzing data and documents, then poured in the form of a design using uml, and stored in a database using MySql, which is implemented using the PHP programming language. the expected results are the creation of orderly administrative regulations to document regulations and decisions (beschikking) that are well-organized and documented.
\end{abstract}

Keywords: Management system, Legal draft, Orderly administration 


\section{PENDAHULUAN}

Dalam pelaksanaan pembuatan peraturan perundang-undangan yang mencakup tahapan perencanaan, penyusunan, pembahasan, pengesahan atau penetapan dan pengundanganpada tahapan perencanaan terkadang terdapat beberapa hal yang dilewatkan, hal ini menyebabkan tidak masuk pada tahapan penyusunan, demikian juga pada tahap penyusunan, terkadang ditemukan beberapa hal yang seharusnya tidak dilaksanakan atau dilaksanakan pada tahapan pembahasan, hal ini terjadi karena tingginya tingkat manualisasi dan pengarsipan, sehingga sangat sulit dalam melakukan pendataan apa saja yang sudah dikerjakan atau yang belum dikerjakan. Berdasarkan hal-hal tersebut di atas, maka perlu membentuk suatu sistem yang baik dalam hal penyusunan sistem informasi regulasi sehingga dapat terwujud mekanisme penyusunan peraturan perundang-undangan berbasis teknologi manajemen informasi untuk membantu melaksanakan tupoksi sub bagian penyusunan peraturan perundang-undangan. Untuk dapat menyelesaikan ini, penulis menggunakan beberapa metode, mulai dari metode analisa data dan dokumen, kemudian dituangkan dalam bentuk rancangan menggunakan uml, dan tersimpan dalam database menggunakan MySql, yang diimplementasikan menggunakan bahasa pemrograman php.hasil yang diharapkan terciptanya regulasi tertib administrasi untuk mendokumentasikan peraturan (regeling) maupun keputusan (beschikking) yang tersusun dan terdokumentasikan secara baik. Legal drating adalahPembentukan Peraturan Perundanganundangan adalah pembuatan Peraturan Perundang-undangan yang mencakup tahapan perencanaan, penyusunan, pembahasan, pengesahan atau penetapan dan pengundangan. Suatu sistem yang terotomatisasi dapat membantu petugas dalam menyelesaikan kewajibanya dangan lebih cepat sehingga mengurangi tingkat keterlambatan yang akan mengganggu stabilitas perusahaan. [1][2]

Kebutuhan akan suatu sistem komputerisasi pada zaman sekarang ini mencakup kesegala bidang yang berhubungan dengan penerapan teknologi informasi [3][16]. Setiap perusahaan swasta maupun pemerintahan sangat membutuhkan sistem komputerisasi yang relevan, akurat, cepat, dan efisien. [4][17]Ketersediaan informasi yang cepat dan akurat serta didukung dengan penerapan sistem yang optimal menjadi kelebihan sendiri harus dimiliki setiap perusahaan. [5][18]Perancangan Sistem adalah suatu kegiatan membuat desain teknis berdasarkan kegiatan pada waktu proses analisis [6][19]. Perancangan disini dimaksudkan suatu proses pemahaman dan peran suatu sistem informasi berbasis komputer [20][7].Monitoring adalah kegiatan memantau yang dilakukan secara rutin mengenai kemajuan project yang sedang berjalan atau kegiatan memantau perubahan proses dan output project.[8][9]

\section{METODE PENELITIAN}

Metode penelitian merupakan suatu tata cara atau kegiatan pelaksanaan penelitian rangka untuk mengumpulkan informasi atau data serta melakukan investigasi terhadap data yang telah didapatkan tersebut. yang didasari oleh asumsi-asumsi dasar, pandangan-pandangan filosofis dan ideologis, pertanyaan dan isu-isu yang dihadapi [10][11]. Suatu penelitian mempunyai rancangan penelitian tertentu. Rancangan ini menggambarkan prosedur atau langkah-langkah yang harus ditempuh, waktu penelitian, sumber data dan kondisi arti untuk apa data dikumpulkan dan dengan cara bagaimana data tersebut dihimpun dan diolah untuk dianalisa dalam pembuatan laporan [12][13].

\subsection{Metode Observasi (Observasi Research)}

Pada tahapan ini penulis melakukan pengamatan langsung dari objek penelitian untuk mendapatkan data dan informasi yang akurat dan lengkap dari berbagai pihak yang terkait dan berhubungan dengan tema penelitian yang berhasil penulis rumuskan.

\section{a. Metode Wawancara (Interview Research)}


Penulis melakukan wawancara dengan bagian terkait yang mengolah data, penulis mendapatkan informasi berkaitan dengan penelitian penulis.

\section{b. $\quad$ Metode Studi Pustaka (Studi Literature)}

Selain melakukan observasi penulis juga melakukan data dengan cara studi pustaka dalam metode ini penulis berusaha untuk melengkapi data-data yang diperoleh dengan membaca dan mempelajari dari buku-buku dan data-data yang relevan dalam pemilihan judul yang penulis ajukan. Buku dan data tersebut digunakan penulis untuk membantu penganalisaan dan perancangan yang dilakukan.

\subsection{Metode Analisis Data}

Pada penelitian ini, metode analisa dilakukan dengan langkah-langkah melakukan pengamatan dan analisa terhadap sistem yangberjalan saat ini, serta menentukan UML (Unified Modeling Language) yang meliputi use case diagram, activity diagram, sequence diagram.

\section{PEMBAHASAN}

Untuk dapat menggambarkan prosedur secara keseluruhan diperlukan bebrapa tahapan analisa sebagai bentuk pengumpulan informasi guna mendapatkan model yang sesuai dengan kebutuhan dan mampu memberikan solusi dengan cepat secara efektif dan efisien, mulai dari tahapan pengumpulan informasi dan kebutuhan, analisa dokumen, merancangan hubungan antar dokumen sampai dengan merancanga model diagram database dan model rancangan sistem [10][11]. Beberapa tahapan yang dimaksud sampai dengan model ranangan yang diciptakan dapat dilihat pada gambar 1,2,3,4,5.

\subsection{Use Case Diagram Prosedur Berjalan}

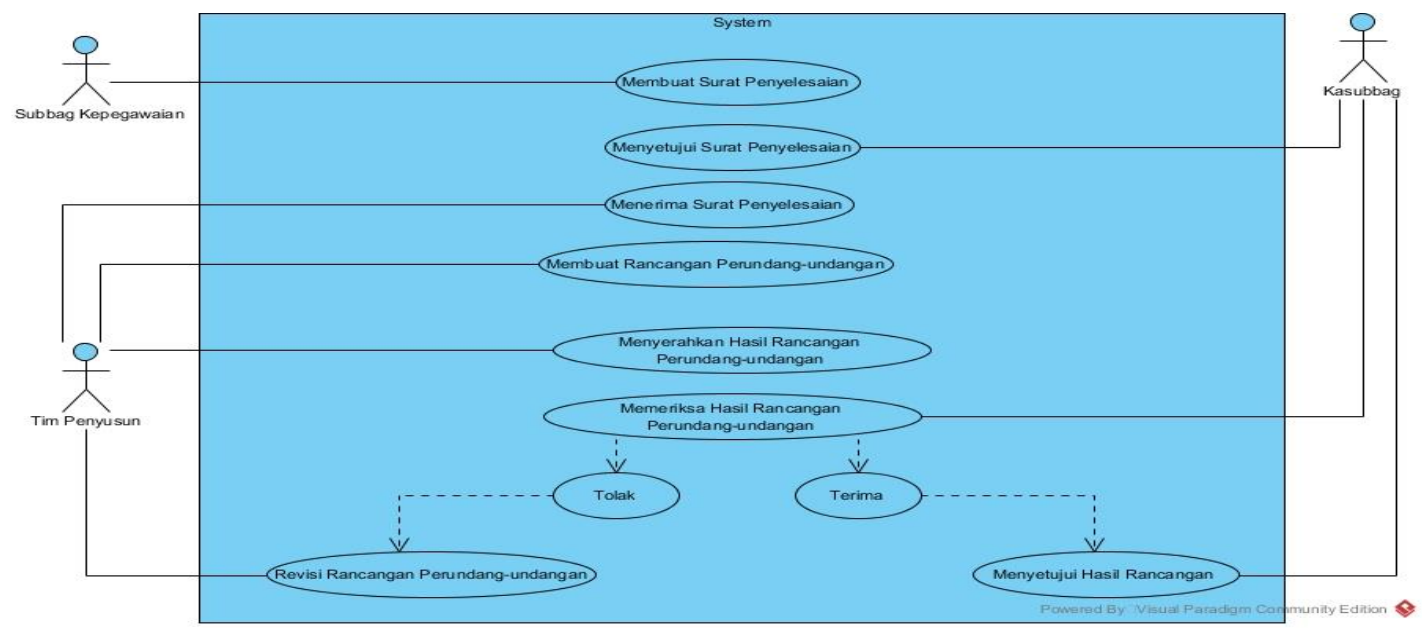

Gambar 1. Use Case Diagram

Berdasarkan gambar use case Diagram(gambar 1) yang berjalan saat ini sistem yang mencakup seluruh kegiatan pada sistem pelaporan legal drafting. Terdapat 3 (tiga) Actor yang melakukan kegiatan yaitu Subbag Kepegawaian, Kasubbag, Tim Penyusun yang berfungsi membuat surat penyelesaian, menyetujui surat penyelesaian, menerima surat penyelesaian, membuat rancangan perundang-undangan, menyerahkan hasil rancangan perundang-undangan, memeriksa hasil rancangan perundang-undangan, diterima, ditolak, revisi rancangan perundangundangan dan menyetujui hasil rancangan.

Terdapat juga 10 (sepuluh) use case yang merupakan proses yang terjadi pada sistem berjalan yaitu membuat surat penyelesaian yang melibatkan Kasubbag Kepegawaian, menyetujui surat penyelesaian yang melibatkan Kasubbag, menerima surat penyelesaian yang melibatkan Tim Penyusun, membuat rancangan perundang-undangan yang melibatkan Tim 
Penyusun, menyerahkan hasil rancangan perundang-undangan yang melibatkan Tim Penyusun, memeriksa hasil rancangan perundang-undangan seperti diterima atau ditolak yang melibatkan Kasubbag, revisi rancangan perundang-undangan apabila ditolak yang melibatkan Tim Penyusun dan menyetujui hasil rancangan apabila diterima yang melibatkan Kasubbag

\subsection{Activity Diagram Prosedur Berjalan}

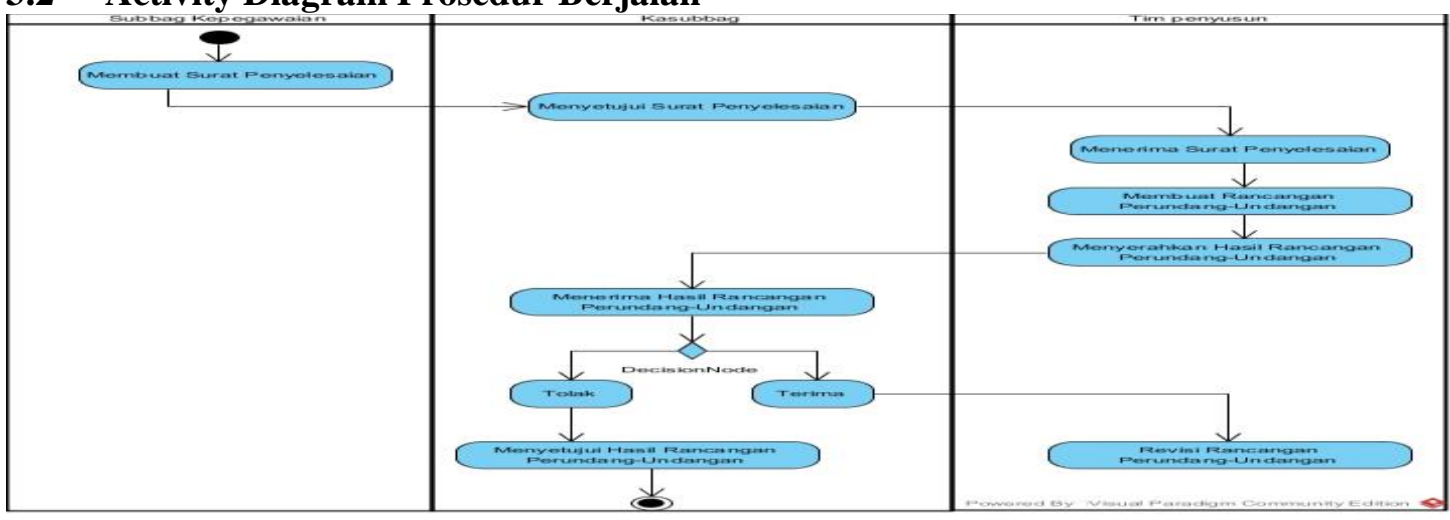

Gambar 2. Activity Diagram

Berdasarkan gambar activity diagram (gambar 2) yang berjalan saat ini sistem mencakup seluruh kegiatan sistem manajemen legal drafting.Sistem ini melibatkan 3 (tiga) Actor yaitu, Subbag Kepegawaian yang membuat surat penyelesaian, kemudian Kasubbag yang menangani menyetujui surat penyelesaian, menerima hasil rancangan perundang-undangan, menolak, menerima dan menyetujui hasil rancangan perundang-undangan, setelah itu Tim Penyusun menangani menerima surat penyelesaian, membuat rancangan perundang-undangan, menyerahkan hasil rancangan perundang-undangan dan revisi rancangan perundang-undangan

\subsection{Sequence Diagram Prosedur Berjalan}

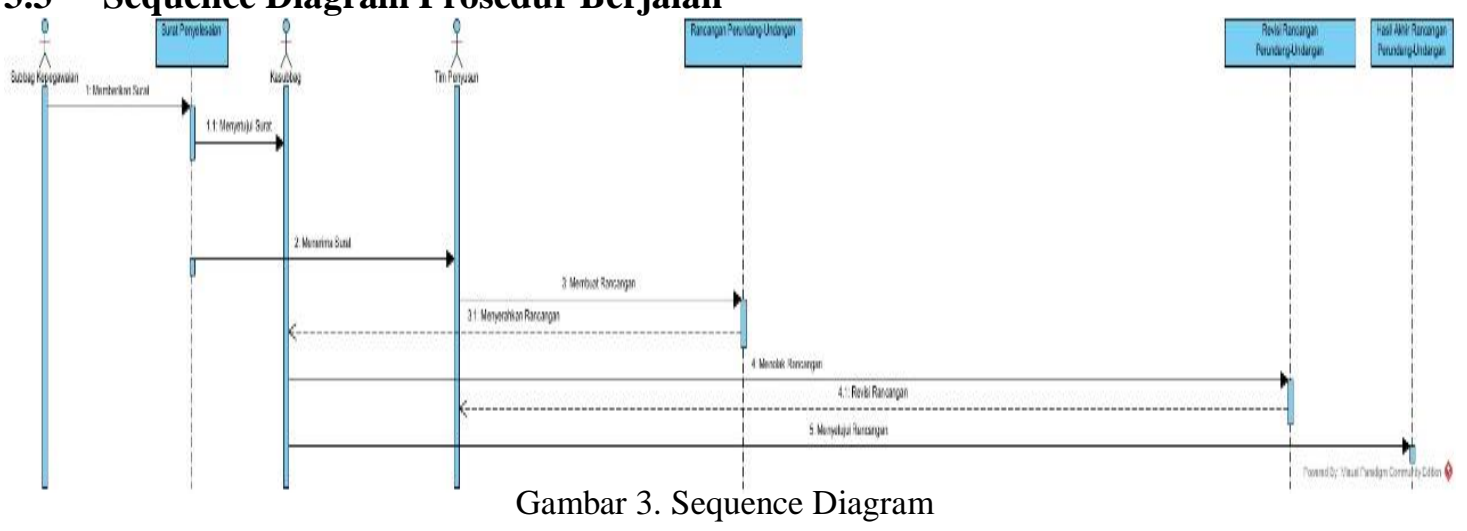

Berdasarkan gambar sequence diagram(gambar 3) yang berjalan saat ini terlihat 3 (tiga) actor yang melakukan kegiatan diantaranya: Subbag Kepegawaian, Kasubbag danTim Penyusun, yang akan menyelesaikan 8 message spesifikasi dari komunikasi antar objek yang memuatinformasi-informasi tentang aktifitas yang terjadi, yaitu menerima surat, menyetujui surat, membuat rancangan, menyerahkan rancangan, menolak rancangan, merevisi rancangan dan menyetujui rancangan

Rancangan diatas (gambar 1, 2, 3) merupakan gambaran prosedur yang berjalan dimana pada tahapan ini melibatkan beberapa dokumen seperti surat penyelesaian, persetujuan surat penyelesaian, rancangan perundang-undangan. Dimana surat penyelesaian dibuat oleh subbag kepegawaian yang berfungsi untuk mengetahui surat masuk dari perusahaan lain untuk membuat izin usaha dan lain-lain. Persetujuan surat penyelesaian dibuat oleh kasubbag yang 
berfungsi untuk pembuatan rancangan perundang-undangan. Rancangan perundang-undangan dibuat oleh tim penyusun yang berfungsi untuk menyampaikan hasil rancangan perundangundangan.

\subsection{Class Diagram}
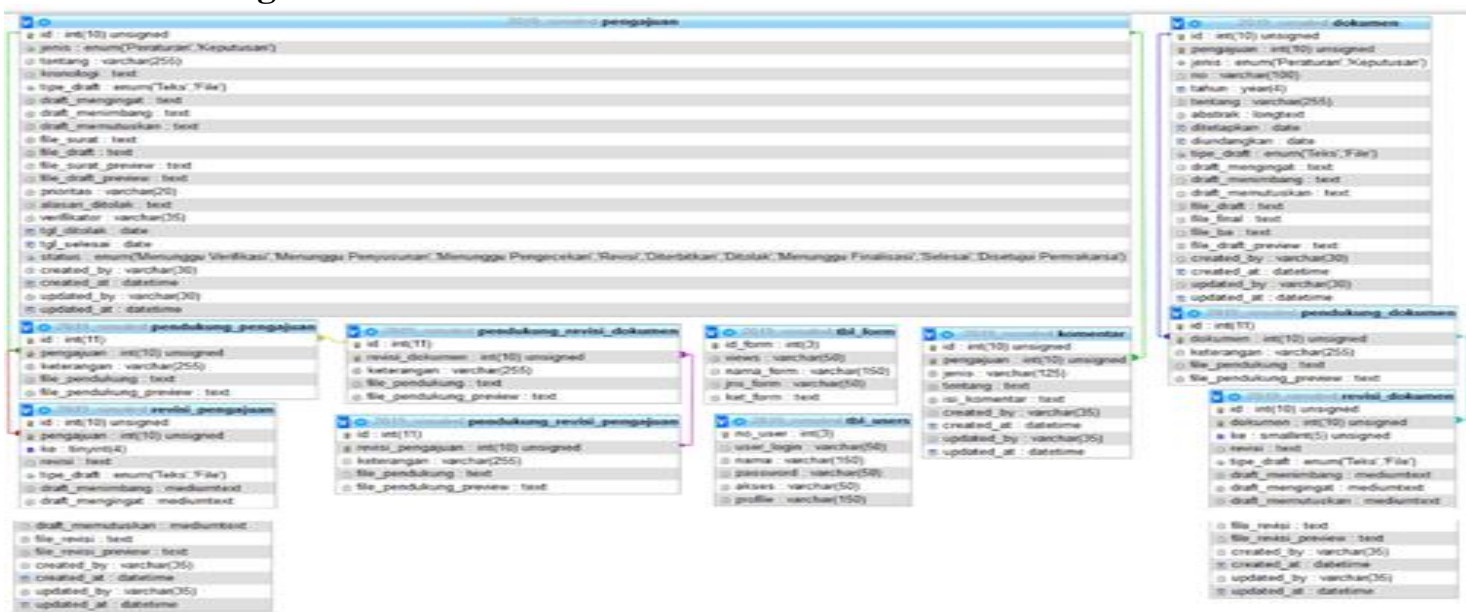

Gambar 4. Class Diagram

Berdasarkan gambar class diagram (gambar 4) yang berjalan saat ini sistem yang mencakup seluruh kegiatan pada sistem manajemen legal drafting. Terdapat 11 (sebelas) class yaitu user dan form yang merupakan tabel master dan pengajuan, dokumen dan komentar sebagai table transaksi, pendukung pengajuan, pendukung revisi pengajuan, pendukung dokumen, pendukung revisi dokumen sebagai menu pendukung, serta tabel revisi dokumen dan revisi pengajuan sebagai menu revisi,

Berdasarkan gambar class diagram (gambar 4) diatas dapat dilihat dengan jelas bahwa tingkat hubungan pengajuandan pendukung pengajuan yaitu one to many (1:M), tingkat hubungan pendukung pengajuan dan revisi pengajuan one to many (1:M), tingkat hubungan pendukung pengajuan dan pendukung revisi dokumen many to one (M:1), tingkat hubungan pendukung revisi dokumen dan pendukung revisi pengajuan many to one (M:1) tingkat hubungan pengajuan dan komentar one to many (1:M), tingkat hubungan dokumen dan pendukung dokumen one to many (1:M), tingakt hubungan pendukung dokumen dan revisi dokumen one to many $(1: \mathrm{M})$

\subsection{Use Case Diagram Usulan}

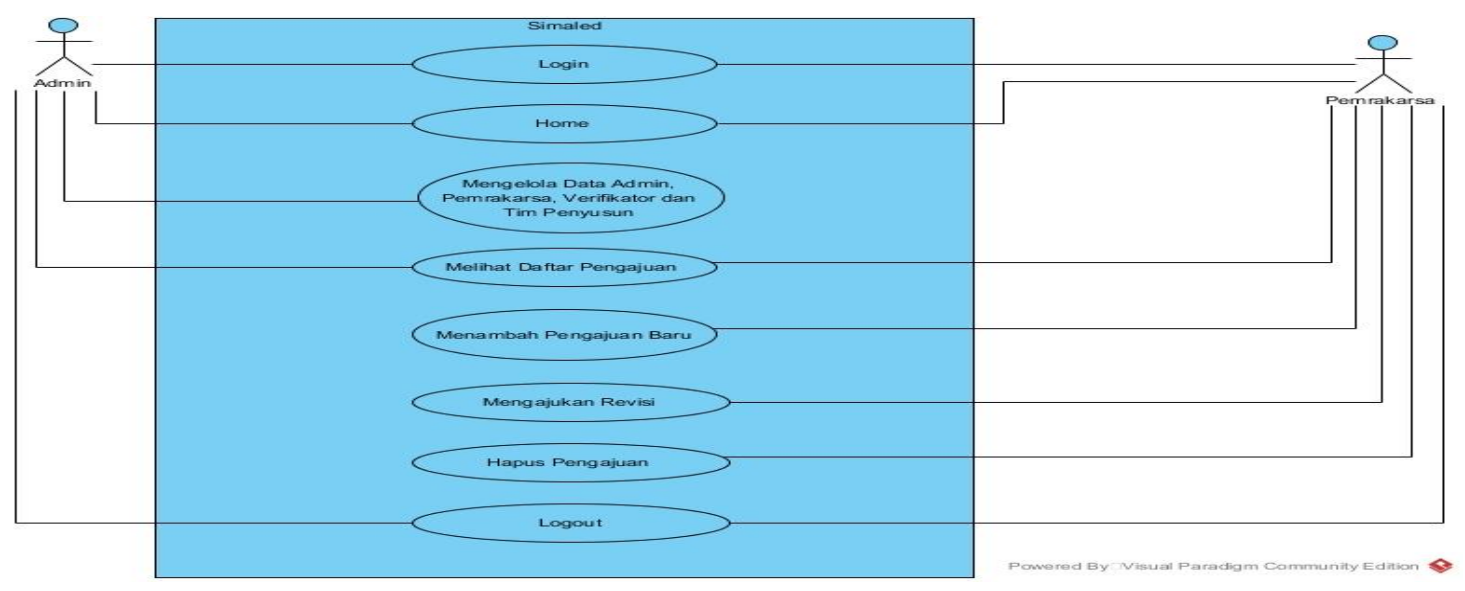

Gambar 5. Use Case Diagram 
Berdasarkan gambar use case diagram usulan (gambar 6 dan 7) terlihat jelas bahwa terdapat 11 (sebelas) use case yang terdiri dari 3 (tiga) use case utama yaitu master, transaksi, report. Use case master memiliki 3 (tiga) yang terdiri dari user yang terhubung dengan actoruser, barang, supplierberhubungan dengan actor user dan actor supplier. Use case transaksi memiliki 4 (empat) yang terdiri dari po, surat jalan, invoice, tanda terima invoice, yang terhubung dengan actor user dan supplier.Use case report memiliki 4 (empat) yang terdiri dari hutang ke supplier, jatuh tempo hutang, presentasi jatuh tempo, estimasi pembayaran yang terhubung dengan actor user dengan pimpinan.

Use diagram sebagai bentuk rancangan sistem yang akan diciptakan (gambar 5) merupakan desain model tampilan utama yang berorintasi pada kebutuhan menu pada aplikasi yang disiapkan, selain itu untuk kebutuhan penyimanan informasi data agar dapat digunakan secara histori juga digambarkan dalam bentuk class diagram (gambar 4) lengkap dengan informasi field dan type data sesuai kebutuhan penyimpanan data.

\subsection{IMPLEMENTASI}

\subsubsection{Rancangan Basis Data}

Untuk dapat menggamarkan bentuk basis data secara utuh, peneliti penggunakan aplikasi microsoft access sebagai bentuk gambaran dasar, dan pada akhirnya bentuk rancangan basis data ini dapat disesuaikan menggunakan apa saja sesuai kebutuhan.

\section{a. Tabel Master: Form}

\begin{tabular}{|c|c|c|c|c|c|c|c|c|}
\hline Prin & tar & Key & : id_form & & & & & \\
\hline For & ig & Key & :- & & & & & \\
\hline Stru & ctu & $\begin{array}{l}\text { e Tabel } \\
\text { Name }\end{array}$ & $:\left\{\mathrm{id}_{\text {Type }}\right.$ form, & $\begin{array}{l}\text { views, nama_form, jns_forn } \\
\text { collation }\end{array}$ & n, ket & form $\}$ & Comments & Extra \\
\hline$\square$ & 1 & id_form & int (3) & & No & None & & \\
\hline$\square$ & 2 & views & varchar(50) & latin1_swedish_ci & Yes & None & & \\
\hline$\square$ & 3 & nama_form & varchar(150) & latin1_swedish_ci & Yes & None & & \\
\hline$\square$ & 4 & jns_form & varchar(50) & latin1_swedish_ci & Yes & None & & \\
\hline$\square$ & 5 & ket_form & text & latin1_swedish_ci & Yes & None & & \\
\hline
\end{tabular}

Tabel 1. Tabel Form

b. Tabel Master: users

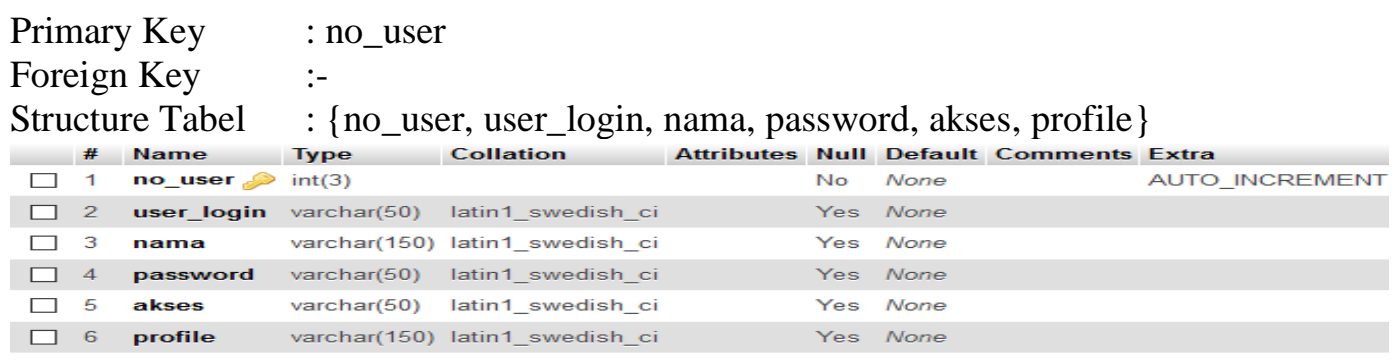

Tabel 2. Tabel Users

\section{c. Tabel Transaksi: Dokumen}

Primary Key : id

Foreign Key : pengajuan

Structure Tabel : $\{$ id, pengajuan, jenis, no, tahun, tentang, abstrak, ditetapkan, diundangkan, tipe_draft, draft_mengingat, draft_menimbang, draft_memutuskan, file_draft, file_final, file_final, file_ba, file_draft_preview, created_by, created_at, updated_by, updated_at 


\begin{tabular}{|c|c|c|c|c|c|c|c|c|}
\hline & $\#$ & Name & Type & Collation & Attributes & Null & Default Comments & Extra \\
\hline$\square$ & 1 & id 2 & $\operatorname{int}(10)$ & & UNSIGNED & No & None & AUTO_INCREMENT \\
\hline$\square$ & 2 & pengajuan & $\operatorname{int}(10)$ & & UNSIGNED & No & None & \\
\hline$\square$ & 3 & jenis & enum('Peraturan', 'Keputusan') & latin1_swedish_ci & & No & None & \\
\hline$\square$ & 4 & no & $\operatorname{varchar}(100)$ & latin1_swedish_ci & & Yes & None & \\
\hline$\square$ & 5 & tahun & year(4) & & & Yes & None & \\
\hline$\square$ & 6 & tentang & $\operatorname{varchar(255)}$ & latin1_swedish_ci & & Yes & None & \\
\hline$\square$ & 7 & abstrak & longtext & latin1_swedish_ci & & Yes & None & \\
\hline$\square$ & 8 & ditetapkan & date & & & Yes & None & \\
\hline$\square$ & 9 & diundangkan & date & & & Yes & None & \\
\hline$\square$ & 10 & tipe_draft & enum(Teks', "File') & latin1_swedish_ci & & No & None & \\
\hline$\square$ & 11 & draft_mengingat & text & latin1_swedish_ci & & Yes & None & \\
\hline$\square$ & 12 & draft_menimbang & text & latin1_swedish_ci & & Yes & None & \\
\hline$\square$ & 13 & draft_memutuskan & text & latin1_swedish_ci & & Yes & None & \\
\hline$\square$ & 14 & file_draft & text & latin1_swedish_ci & & Yes & None & \\
\hline$\square$ & 15 & file_final & text & latin1_swedish_ci & & Yes & None & \\
\hline$\square$ & 16 & file_ba & text & latin1_swedish_ci & & Yes & None & \\
\hline$\square$ & 17 & file_draft_preview & text & latin1_swedish_ci & & Yes & None & \\
\hline$\square$ & 18 & created_by & $\operatorname{varchar}(30)$ & latin1_swedish_ci & & No & None & \\
\hline$\square$ & 19 & created_at & datetime & & & Yes & None & \\
\hline$\square$ & 20 & updated_by & $\operatorname{varchar}(30)$ & latin1_swedish_ci & & No & None & \\
\hline$\square$ & 21 & updated_at & datetime & & & Yes & None & \\
\hline
\end{tabular}

Tabel 3. Tabel Dokumen

\section{d. Tabel Transaksi: Komentar}

Primary Key : : id

Foreign Key $\quad:$ ppengajuan

Structure Tabel : $\{$ id, pengajuan, jenis, tentang, isi_komentar, created_by, created_at, updated_by, updated_at

\begin{tabular}{|c|c|c|c|c|c|c|c|c|}
\hline & \# & Name & Type & Collation & Attributes & Null & Default Comments & Extra \\
\hline$\square$ & 1 & id & $\operatorname{int}(10)$ & & UNSIGNED & No & None & AUTO_INCREMENT \\
\hline$\square$ & 2 & pengajuan & $\operatorname{int}(10)$ & & UNSIGNED & No & None & \\
\hline$\square$ & 3 & jenis & varchar(125) & latin1_swedish_ci & & No & None & \\
\hline$\square$ & 4 & tentang & text & latin1_swedish_ci & & No & None & \\
\hline$\square$ & 5 & isi_komentar & text & latin1_swedish_ci & & No & None & \\
\hline$\square$ & 6 & created_by & varchar(35) & latin1_swedish_ci & & No & None & \\
\hline$\square$ & 7 & created_at & datetime & & & No & None & \\
\hline$\square$ & 8 & updated_by & varchar(35) & latin1_swedish_ci & & No & None & \\
\hline$\square$ & 9 & updated_at & datetime & & & Ye & None & \\
\hline
\end{tabular}

Tabel 4. Tabel Komentar

\section{e. Tabel Transaksi: Pendukung Dokumen}

Primary Key : : id

Foreign Key : dokumen

Structure Tabel : $\{$ id, dokumen, keterangan, file_pendukung, file_pendukung_preview

\begin{tabular}{|c|c|c|c|c|c|c|c|c|}
\hline & $\#$ & Name & Type & Collation & Attributes & Null & Default Comments & Extra \\
\hline$\square$ & 1 & id & $\operatorname{int}(11)$ & & & No & None & AUTO_INCREMENT \\
\hline$\square$ & 2 & dokumen & $\operatorname{int}(10)$ & & UNSIGNED & No & None & \\
\hline$\square$ & 3 & keterangan & $\operatorname{varchar}(255)$ & latin1_swedish_ci & & No & None & \\
\hline$\square$ & 4 & file_pendukung & text & latin1_swedish_ci & & No & None & \\
\hline$\square$ & 5 & file_pendukung & text & latin1_swedish_ci & & No & None & \\
\hline
\end{tabular}

Tabel 5. Tabel Pendukung Dokumen

\section{f. Tabel Transaksi: Pendukung Pengajuan}

Primary Key : id

Foreign Key : pengajuan

Structure Tabel : $\{$ id, pengajuan, keterangan, file_pendukung, file_pendukung_preview 


\begin{tabular}{|c|c|c|c|c|c|c|c|c|c|}
\hline & \# & Name & Type & Collation & Attributes & Null & Default & Comments & Extra \\
\hline$\square$ & 1 & id $?$ & $\operatorname{int}(11)$ & & & No & None & & AUTO_INCREMENT \\
\hline$\square$ & 2 & pengajuan & $\operatorname{int}(10)$ & & UNSIGNED & No & None & & \\
\hline$\square$ & 3 & keterangan & varchar(255) & latin1_swedish_ci & & No & None & & \\
\hline$\square$ & 4 & file_pendukung & text & latin1_swedish_ci & & No & None & & \\
\hline$\square$ & 5 & file_pendukung_preview & text & latin1_swedish_ci & & No & None & & \\
\hline
\end{tabular}

Tabel 6. Tabel Pendukung Pengajuan

\section{g. Tabel Transaksi: Pendukung Revisi Dokumen}

Primary Key : id

Foreign Key : revisi_dokumen

Structure Tabel : $\{$ id, $\quad$ revisi_dokumen, keterangan, file_pendukung, file_pendukung_preview

\begin{tabular}{|c|c|c|c|c|c|c|c|c|}
\hline & $\#$ & Name & Type & Collation & Attributes & Null & Default Comments & Extra \\
\hline$\square$ & 1 & id $P$ & $\operatorname{int}(11)$ & & & No & None & AUTO_INCREMENT \\
\hline$\square$ & 2 & revisi_dokumen & $\operatorname{int}(10)$ & & UNSIGNED & No & None & \\
\hline$\square$ & 3 & keterangan & $\operatorname{varchar}(255)$ & latin1_swedish_ci & & No & None & \\
\hline$\square$ & 4 & file_pendukung & text & latin1_swedish_ci & & No & None & \\
\hline$\square$ & 5 & file_pendukung_preview & text & latin1_swedish_ci & & No & None & \\
\hline
\end{tabular}

Tabel 7. Tabel Pendukung Revisi Dokumen

h. Tabel Transaksi: Pendukung Revisi Pengajuan

Primary Key : id

Foreign Key : revisi_pengajuan

Structure Tabel : $\{$ id, $\quad$ revisi_pengajuan, keterangan, file_pendukung, file_pendukung_preview

\begin{tabular}{|c|c|c|c|c|c|c|c|c|}
\hline & \# & Name & Type & Collation & Attributes & Null & Default Comments & Extra \\
\hline$\square$ & 1 & id $P$ & $\operatorname{int}(11)$ & & & No & None & AUTO_INCREMENT \\
\hline$\square$ & 2 & revisi_pengajuan & $\operatorname{int}(10)$ & & UNSIGNED & No & None & \\
\hline$\square$ & 3 & keterangan & varchar(255) & latin1_swedish_ci & & No & None & \\
\hline$\square$ & 4 & file_pendukung & text & latin1_swedish_ci & & No & None & \\
\hline$\square$ & 5 & file_pendukung_preview & text & latin1_swedish_ci & & No & None & \\
\hline
\end{tabular}

Tabel 8. Tabel Pendukung Revisi Pengajuan

\section{i. Tabel Transaksi: Pengajuan}

Primary Key : : id

Foreign Key : :-

Structure Tabel : $\{\mathrm{id}, \quad$ jenis, tentang, kronologi, tipe_draft, draft_mengingat, draft_menimbang, draft_memutuskan, file_surat, file_draft, file_surat_preview, file_draft_preview, prioritas, alas an_ditolak, verifikator, tgl_ditolak, tgl_selesai, status, created_by, created_at, updated_by, updated_at 


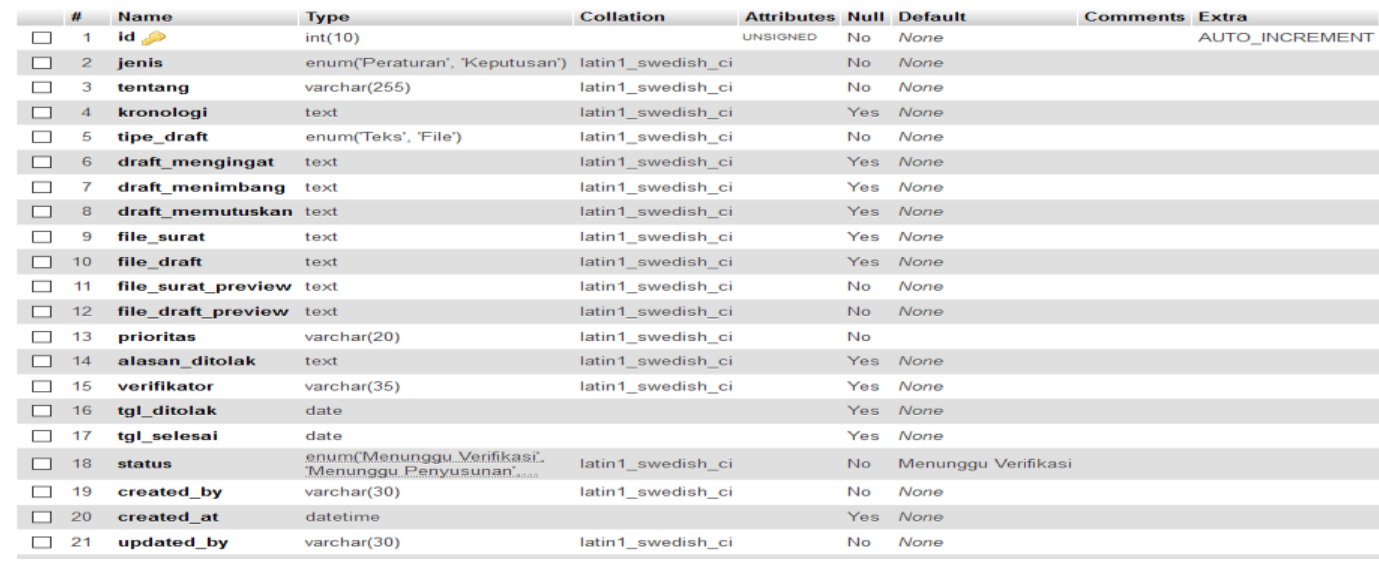

Tabel 9. Pengajuan

\section{j. $\quad$ Tabel Transaksi: Revisi Pengajuan}

Primary Key : : id

Foreign Key : pengajuan

Structure Tabel : \{id, pengajuan, ke, revisi, tipe_draft, draft_menimbang, draft_mengingat, draft_memutuskan, file_revisi, file_revisi, file_revisi_preview, created_by, created_at, updated_by, updated_at

\begin{tabular}{|c|c|c|c|c|c|c|c|c|}
\hline & \# & Name & Type & Collation & Attributes & Null & Default Comments & Extra \\
\hline$\square$ & 1 & id & $\operatorname{int}(10)$ & & UNSIGNED & No & None & AUTO_INCREMENT \\
\hline$\square$ & 2 & pengajuan & $\operatorname{int}(10)$ & & UNSIGNED & No & None & \\
\hline$\square$ & 3 & ke & tinyint(4) & & & No & None & \\
\hline$\square$ & 4 & revisi & text & latin1_swedish_ci & & No & None & \\
\hline$\square$ & 5 & tipe_draft & enum(Teks", "File') & latin1_swedish_ci & & No & None & \\
\hline$\square$ & 6 & draft_menimbang & mediumtext & latin1_swedish_ci & & Yes & None & \\
\hline$\square$ & 7 & draft_mengingat & mediumtext & latin1_swedish_ci & & Yes & None & \\
\hline$\square$ & 8 & draft_memutuskan & mediumtext & latin1_swedish_ci & & Yes & None & \\
\hline$\square$ & 9 & file_revisi & text & latin1_swedish_ci & & Yes & None & \\
\hline$\square$ & 10 & file_revisi_preview & text & latin1_swedish_ci & & Yes & None & \\
\hline$\square$ & 11 & created_by & $\operatorname{varchar}(35)$ & latin1_swedish_ci & & Yes & None & \\
\hline$\square$ & 12 & created_at & datetime & & & Yes & None & \\
\hline$\square$ & 13 & updated_by & varchar(35) & latin1_swedish_ci & & Yes & None & \\
\hline$\square$ & 14 & updated_at & datetime & & & Yes & None & \\
\hline
\end{tabular}

Tabel 10. Tabel Revisi Pengajuan

\subsection{Grafik Jumlah Surat Dalam 3 Tahun Terakhir}

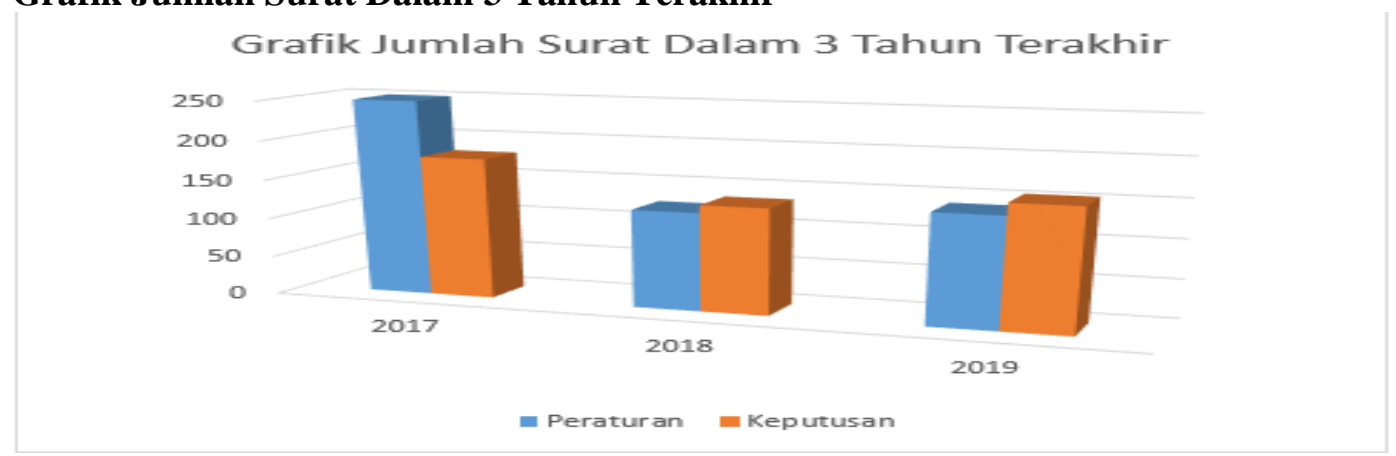

Gambar6. Grafik Jumlah Surat

Grafik diatas (gambar 8) merupakan grafik Jumlah Suratmonitoring berdasarkan waktu (tahun). Hal ini bisa membantu mengetahu berapa surat yang termasuk peraturan dan keputusan setiap tahunnya.Grafik diatas bisa diambil berdasarkan Datewarehouse, sebagaimana di definisikan "Doing Data Warehouse $(D W)$ to your business or system is not only think about the trend only, but how to understand the DW knowledge itself and how to implement it" [14]. Dan 
bagaimana cara mengukurnya "Measures are a standard unit used to express the size, amount, or degree of something, qualities are often difficult to be measured as it needs to have some certain parameter or elements, and those parameters must be quantifiable and verifiable" [15].

\subsection{Diagram HIPO}

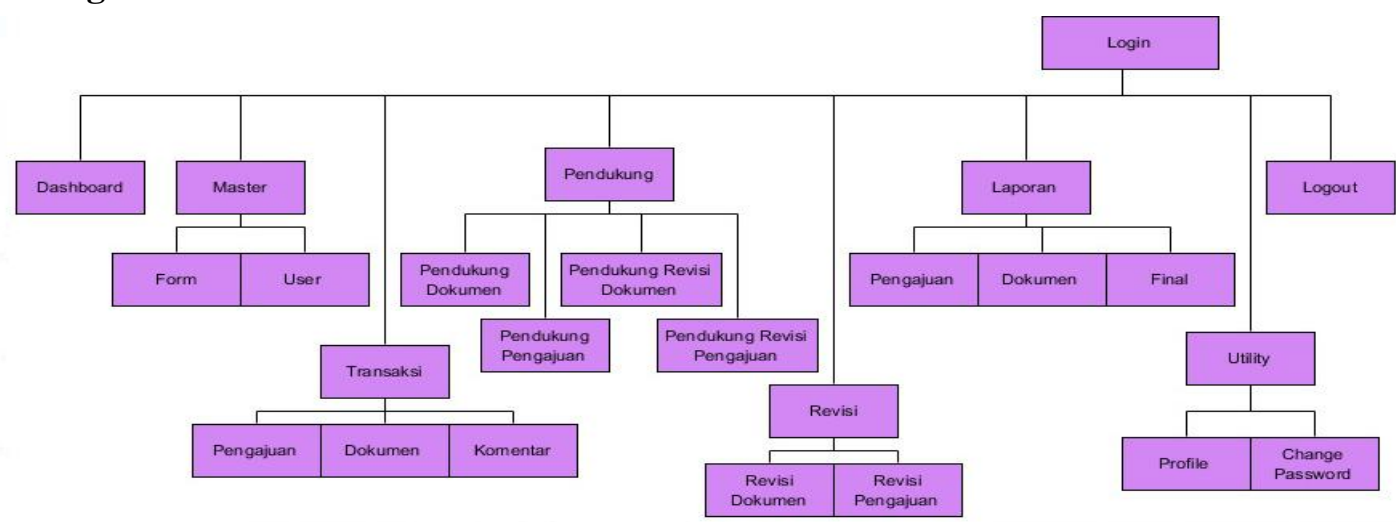

Gambar 7. Gambar HIPO

Untuk menggambarkan stuktur menu dari sistem yang dirancang dapat digambarkan dengan diagram HIPO (Hierarchy Input Process Output).Untuk menyediakan suatu struktur guna memahami fungsi-fungsi dari program.Terlihat dari diagram HIPO diatas (gambar 7) terdapat 1 (satu) fungsi utama (digram 0) dan 3 (tiga) fungsi dibawahnya, yaitu fungsi menu master (diagram 1), menu transaksi (diagram 2) dan menu report (diagram 3). Didalam fungsi menu master (diagram 1) terdapat 3 (tiga) fungsi sub menu yaitu fungsi menu pengelolaan data user (diagram 1.1), pengelolaan data suplier (diagram 1.2) dan pengelolaan data barang (diagram 1.3). Didalam fungsi menu transaksi (diagram 2) terdapat 4 (empat) fungsi fungsi sub menu yaitu fungsi menu pengelolaan data po (diagram 2.1), pengelolaan data surat jalan (diagram 2.2), pengelolaan data invoice (diagram 2.3) dan pengelolaan data tanda terima invoice (diagram 2.4). Didalam fungsi report (diagram 3) terdapat 4 (empat) fungsi sub menu yaitu fungsi menu pengelolaan data tagihan supplier (diagram 4.1), pengelolaan jatuh tempo hutang (diagram 4.2), pengelolaan presentasi jatuh tempo (diagram 4.3) dan pengelolaan data estimasi pembayaran (diagram 3.4).

\subsection{Rancangan Tampilan}

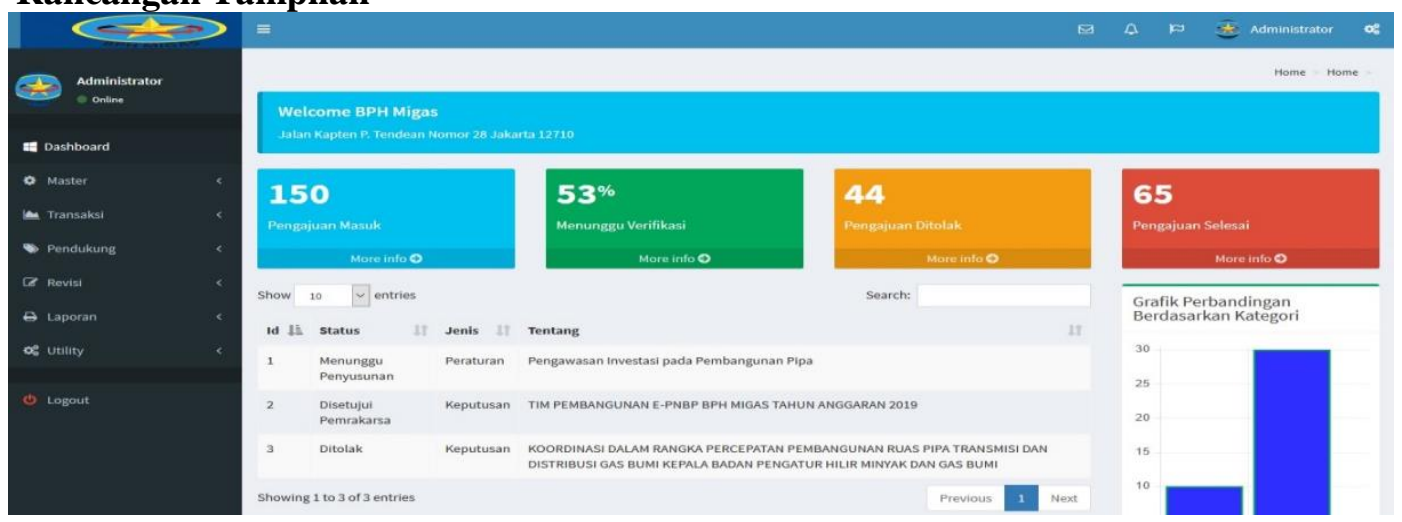

Gambar 8 Tampilan Halaman Utama

Terlihat pada tampilan layar diatas (gambar 10) merupakan tampilan layar utama yang terdiri dari menu master, menu transaksi, menu pendukung, menu laporan dan utility 


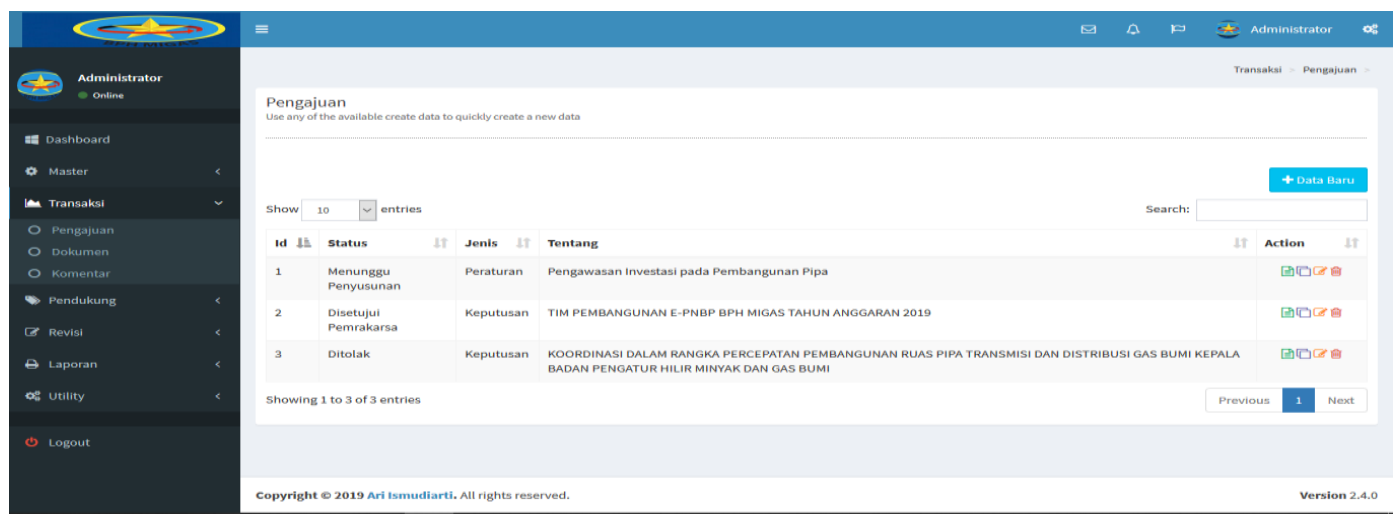

Gambar 9 Tampilan Menu Transaksi

Terlihat pada tampilan layar diatas (gambar 11) merupakan tampilan layar utama yang terdiri dari menu master, menu transaksi, menu pendukung, menu revisi, laporan dan utility, dimana menu transaksi memiliki sub menu pengajuan, sub menu dokumen dan sub menu komentar.

\subsection{Query Pengajuan}

Query List Pengajuan:

function list_pengajuan()

$\{\quad \$$ sql="select * from pengajuan"; $\quad \$$ this- $>$ sql $=\$$ sql; $\$ \mathrm{i}=0 ;$

\$query=\$this->mysqli->query $(\$$ sql $)$ or die (\$this->mysqli->error () ); while (\$result=\$query->fetch_assoc())

\{ \$this->id[\$i] $=\$$ result['id'];

\$this->jenis[\$i]=\$result['jenis'];

\$this->tentang[\$i]=\$result['tentang'];

\$this-> kronologi[\$i]=\$result['kronologi'];

\$this->tipe_draft[\$i] $=\$$ result['tipe_draft'];

\$this->draft_mengingat[\$i]=\$result['draft_mengingat'];

\$this->draft_menimbang[\$i]=\$result['draft_menimbang'];

\$this->draft_memutuskan[\$i]=\$result['draft_memutuskan'];

\$this->file_surat[\$i]=\$result['file_surat'];

\$this->file_draft[\$i]=\$result['file_draft'];

\$this->file_surat_preview[\$i]=\$result['file_surat_preview'];

\$this->file_draft_preview[\$i]=\$result['file_draft_preview'];

\$this->prioritas[\$i] $=\$$ result['prioritas'];

\$this->alasan_ditolak[\$i]=\$result['alasan_ditolak'];

\$this->verifikator[\$i]=\$result['verifikator'];

\$this->tgl_ditolak[\$i]=\$result['tgl_ditolak'];

\$this->tgl_selesai[\$i] =\$result['tgl_selesai'];

\$this->status[\$i] $=\$$ result['status'];

\$this->created_by[\$i]=\$result['created_by'];

\$this->created_at[\$i] $=\$$ result['created_at'];

\$this-> updated_by[\$i]=\$result['updated_by'];

\$this-> updated_at[\$i]=\$result['updated_at'];

$\$ \mathrm{i}++; \quad\} \quad$ return true; $\$$ this->mysqli->close ()$; \quad\}$

\section{Query Simpan Pengajuan:}

function simpan_pengajuan()

\{ \$sql="insert into pengajuan 


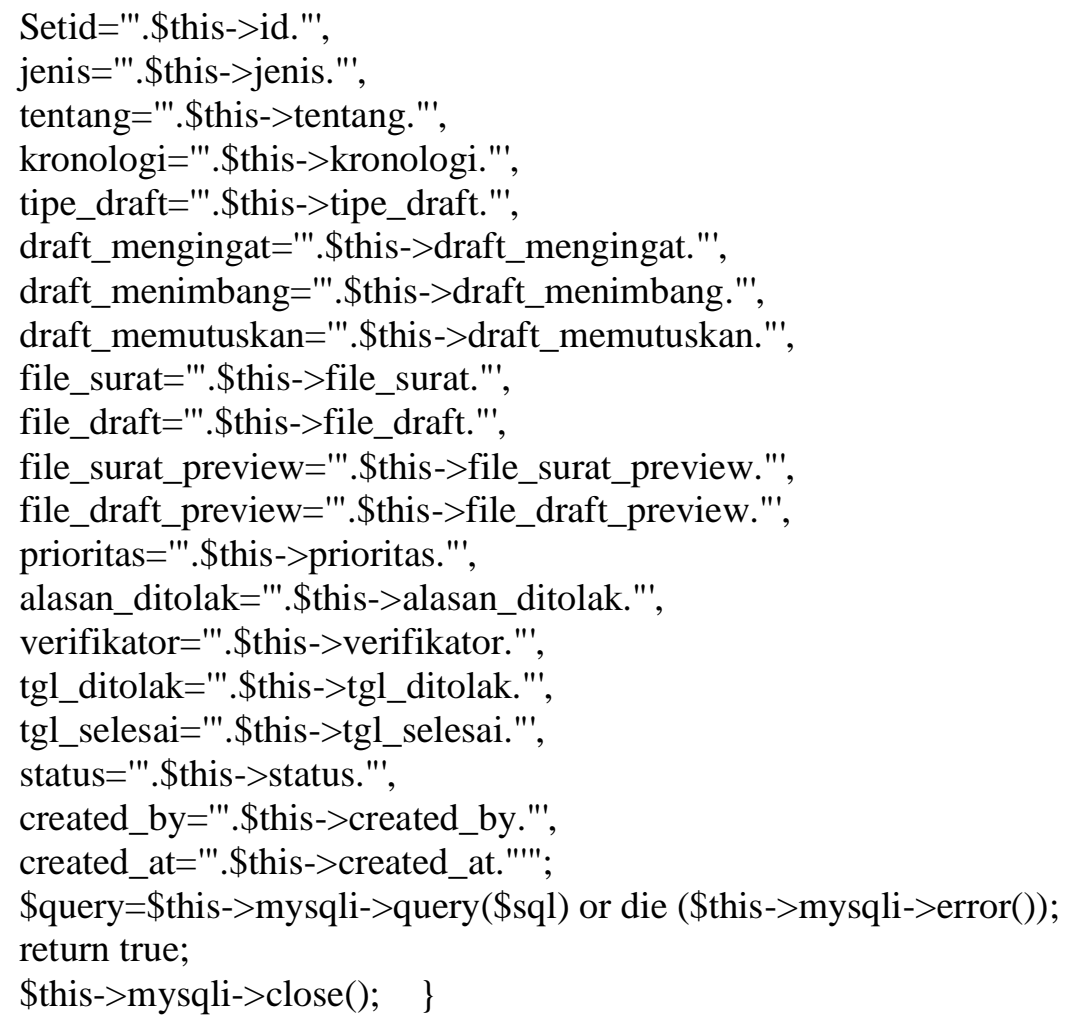

\section{KESIMPULAN}

Berdasarkan dari hasil analisa dari rumusan masalah yang telah dilakukan, maka dapat disimpulkan bahwa manajemen legal drafting yang berjalan masih menggunakan aplikasi Ms. Office dimana dalam pengelolaan datanya memakan waktu yang lama dan dalam penyajian laporan kurang akurat. Selain itu manajemen legal drafting yang sedang berjalan saat ini masih menggunakan metode semikomputerisasi yang harus melalui proses yang cukup rumit sehingga membutuhkan waktu yang lama.Sistem yang berjalan saat ini belum berjalan dengan baik karena proses dilakukan secara manual yang dapat menyebabkan salah dalam pemilahannya atau human error sehingga akurasi data masih rendah.Sistem usulan yang dirancang agar dapat menghasilkan laporan pengajuan yang cepat dan akurat, sehingga tidak ada lagi keterlambatan atau kesalahan dalam penginputan data pengajuan maupun penyelesaian laporan pengajuan, sehingga mampu menciptakan tertib administrasi. Hal ini tentunya diselesaikan dengan berbagai metode penelitian mulai dari analisa data dan dokumen sampai dengan perancangan sistem menggunakan uml dan penyimpanan database menggunakan MySql dengan bahasa pemrograman php.

\section{SARAN}

Adapun saran yang dapat diberikan peneliti sebagai gambaran untuk mengatasi pemecahan masalah yang terjadi pada sistem manajemen legal drafting antara lain :

1. Sistem pengarsipan legal drafting yang belum terkomputerisasi sebaiknya segera direalisasikan agar sistem yang berjalan bisa segera terintegrasi dengan baik.

2. Diharapkan dalam proses pengajuan di dukung dengan sistem terkomputerisasi yang akan jauh lebih membantu dalam pekerjaan dan akan lebih efektif dan efisien.

3. Sistem yang diusulkan akan menampung banyak data, diharapkan pihak BPH Migas menyediakan komputer dengan media penyimpanan yang lebih besar 


\section{DAFTAR PUSTAKA}

[1] Junaidi, J., Roji, A., \& Munawar, K. (2015). Konsep Otomatisasi Sistem Pembayaran SPP Online Untuk Mengurangi Tingkat Keterlambatan. Proceedings Konferensi Nasional Sistem dan Informatika (KNS\&I).

[2] Lestari, Endang. 2009. Analisa Sistem Pendukung Keputusan Untuk Proses Kenaikan Jabatan pada PT. X, Jurnal Sistem Informasi, 1, 141-150.

[3] Junaidi, T. K. Y. N. D. (2013). Sistem Pakar Monitoring Inventory Control Untuk Menghitung Harga Jual Efektif Dalam Meningkatkan Keuntungan. Yogyakarta: Universitas Ahmad Dahlan.

[4] Purwanti, Endang. 2008. Assesment Pembelajaran SD. Jakarta : Depdiknas.

[5] Junaidi, J., Effendy, M. Y., \& Hartono, H. (2015). REKAYASA MODEL APLIKASI SISTEM PRODUCT KNOWLADGE UNTUK MENDUKUNG PENGAMBILAN KEPUTUSAN DALAM MENENTUKAN KINERJA KARYAWAN. CERITA Journal, 1(1), 46-55.

[6] Henderi, H., Junaidi, J., \& Kusuma, T. A. H. (2012). Dashboard Monitoring System Penjualan Dan Reward Mobile Kios PT. Telekomunikasi Seluler. Semantik, 2(1).

[7] Junaidi, J., Arifin, R., \& Septiani, A. (2015). Rancang Bangun Aplikasi Sistem Inventory Berbasis Desktop Menggunakan JSE. Proceedings Konferensi Nasional Sistem dan Informatika (KNS\&I).

[8] Hidayat, Wahyu, Riri Mahmuriyah, dan Sri Ndayani Ratna Safitri. 2016. Media Visual Berbentuk Katalog Produk Sebagai Media Promosi. ISSN: 2461-1409. Jurnal SENSI Vol.2 No. 2-Agustus 2016. Tangerang : Perguruan Tinggi Raharja.

[10] Asbar, Yuli, dan Mochamad Ari Saptari. 2017. "Analisa Dalam Mengukur Kualitas Pelayanan Terhadap Kepuasan Konsumen Menggunakan Metode PIECES". Jurnal Visioner \& Strategis Vol. 6 Nomor 2, September 2017: 39-47 Universitas Malikussaleh.

[11] Junaidi, J., Santoso, S., \& Sunarya, L. (2008). Rekayasa Teknik Pemrograman Pencegahan Dan Perlindungan Dari Virus Lokal Menggunakan API Visual Basic. CCIT Journal, 1(2), 134-153.

[12] Martono, A., \& Junaidi, D. Y. IMULATION GAME BASED ON JARIMAGIC METHOD TO CALCULATE MORE QUICKLY FOR ELEMENTARY STUDENTS.

[13] Junaidi, J., Cholisoh, N., \& Hasanah, N. (2018). Rancang Bangun Sistem Manajemen Aset IT Untuk Pencatatan History Maintenance Sebagai Pendukung Keputusan. SENSI Journal, 4(2), 220-231.

[14] M. Subekti, Warnars Junaidi, H.L.H.S., Y. Heryadi, "The 3 steps of best data warehouse model design with leaning implementation for sales transaction in franchise restaurant", Cybernetics and Computational Intelligence (CyberneticsCom) 2017 IEEE International Conference on, 20-22 Nov 2017.

[15] J. Junaidi, A. Julianto, N. Anwar, S. Safrizal, H.L.H.S. Warnars, K. Hashimoto, "Perfecting a Video Game with Game Metrics", Telkomnika, vol. 16, no. 3, pp. 13241331, June 2018 
[16] Zainuddin, A., Junaidi, J., \& Putra, R. D. (2017). Design of E-Commerce Payment System at Tokopedia Online Shopping Site. Aptisi Transactions On Management, 1(2), 143-155.

[17] Junaidi, J., Sutrisno, S., \& Janah, K. (2019). MODEL APLIKASI PURCHASING SYSTEM UNTUK MONITORING STOK DALAM MENGURANGI TINGKAT KERUGIAN. SENSI Journal, 5(1), 86-98.

[18] AMALIA, Riski, et al. PEMODELAN APLIKASI INTEGRATED LEARNING SYSTEM BERBASIS MOBILE. SEMNASTEKNOMEDIA ONLINE, 2013, 1.1: 20-45.

[19] Henderi, H., Nuraeni, Y., Junaidi, J., \& Hidayat, R. (2010). IT GOVERNANCE: A STRATEGIC ALIGNMENT FOR INFORMATION TECHNOLOGY/BUSINESS. CCIT Journal, 4(1), 57-69.

[20] Junaidi, J., Alfiah, F., Susanti, E., Kristinna, J., Ardiansyah, O. R., Pradipta, D., \& Wulaningsih, W. (2015). MANFAAT MENGANALISIS PENGARUH SOSIAL MEDIA FACEBOOK TERHADAP KAMPANYE PARTAI POLITIK DI INDONESIA. SEMNASTEKNOMEDIA ONLINE, 3(1), 4-5. 